\title{
Oncological and functional outcomes of 244 laparoscopic urological procedures: Cumhuriyet University experience
}

\section{Laparoskopik ürrolojik cerrahi uygulanan 244 olgunun kısa dönem onkolojik ve fonksiyonel sonuçları: Cumhuriyet Üniversitesi deneyimi}

\author{
Kaan Gökçen ${ }^{1}$, Emre Kıraç², Resul Çiçek², Gökhan Gökçe
}

\begin{abstract}
${ }^{1}$ Assistant Professor, Cumhuriyet University, School of Medicine, Department of Urology, Sivas, Turkey
${ }^{2}$ Resident, Cumhuriyet University, School of Medicine, Department of Urology, Sivas, Turkey

${ }^{3}$ Professor, Cumhuriyet University, School of Medicine, Department of Urology, Sivas, Turkey

Corresponding author: Kaan Gökçen, Assistant Professor, M.D. Cumhuriyet University, School of Medicine, Department of Urology, Sivas,

Turkey

E-mail: kaangokcen@hotmail.com

Received/Accepted: February 23, 2018 / March 05, 2018
\end{abstract}

Conflict of interest: There is not a conflict of interest.

\begin{abstract}
SUMMARY
Objective: Presenting short-term oncological and functional outcomes of laparoscopic procedures performed in the past two years in the Urology Department of Cumhuriyet University Health Services Training and Research Hospital.

Method: Clinical data of a total of 244 patients, including 13 pediatric patients, who underwent laparoscopic surgery between May 2015 and February 2018 were evaluated retrospectively.

Results: Of the patients who underwent laparoscopic surgery, $139(57 \%)$ were male and 105 (43\%) were female, 13 $(5 \%)$ were pediatric and the mean age of the patients was $52.6 \pm 17.6$ (1-83). Radical nephrectomy was performed in 47 patients, radical prostatectomy was performed in 46 patients, simple nephrectomy was performed in 37 patients, renal cyst excision was performed in 35 patients, partial nephrectomy was performed in 26 patients, dismembered pyeloplasty was performed in 25 patients 13 of whom were pediatric, adrenalectomy was performed in 15 patients, ureterolithotomy was performed in 8 patients, pyelolithotomy was performed in 2 patients, sacrocolpopexy was performed in 2 patients, and due to undescended testicle diagnosis, laparoscopy was performed in 1 patient. The mean duration of operation was $101.9 \pm 62.7$ (20-270) minutes and the mean amount of bleeding was found as $154.3 \pm 138.7(5-800) \mathrm{ml}$. Transperitoneal approach was preferred in all other cases except extraperitoneal radical prostatectomy. Blood transfusion was required in twenty-six cases, fourteen of which were laparoscopic radical prostatectomy in perioperative and / or postoperative periods. There was no need for initiating intraoperative open surgery except one case. In one case, laparotomy was required due to bleeding on the 4th postoperative day. In six cases, superficial wound site infection developed. The mean duration of postoperative hospitalization was $3.8 \pm 2.7$ days (1-8 days). The mean follow-up period of our patients was 16.5 (0-33) months.

Conclusions: Laparoscopic urological surgeries are frequently preferred as minimally invasive procedures being technically well-defined, with good oncological and functional outcomes, as well as with short hospitalization periods and cosmetic advantages.
\end{abstract}

Keywords: Laparoscopy, radical prostatectomy, nephrectomy, adrenalectomy, pyeloplasty. 
ÖZET

Amaç: Cumhuriyet Üniversitesi Sağlık Hizmetleri Uygulama ve Araştırma Hastanesi Üroloji kliniğgindeki son iki yılda gerçekleştirilen laparoskopik girişimlerin kısa dönem onkolojik ve fonksiyonel sonuçlarını sunmaktır

Yöntem: Mayıs 2015 ile Şubat 2018 tarihleri arasında kliniğimizde laparoskopik cerrahi uygulanan 13’ü pediatrik olan toplam 244 olguya ait olan veriler retrospektif olarak değerlendirilmiştir.

Bulgular: Laparoskopik cerrahi yapılan hastaların 139’ u (57\%) erkek, 105' i kadın (43\%) ve bu hastaların 13' ü (5\%) pediatrik olup hastaların ortalama yaşı $52.6 \pm 17.6$ (1-83) idi. Hastaların 47'sine radikal nefrektomi, 46' sına radikal prostatatektomi, 37'sine basit nefrektomi, 35' ine renal kist eksizyonu, 26' sina parsiyel nefrektomi, 13' ü pediatrik olan 25 olguya dismembered pyeloplasti 15' ine adrenalektomi, 8' ine üreterolitotomi, 2' sine pyelolitotomi, , 2'sine sarkokolpopeksi, 1' ine ise inmemiş testis nedeniyle tanısal laparoskopi uygulanmıştır. Ortalama operasyon süresi 101.9 \pm 62.7 (20-270) dakika olup kanama miktarı ise ortalama $154.3 \pm 138.7$ (5-800) ml olarak hesaplanmıştır. Ekstraperitoneal olarak uygulanan radikal prostatektomi haricinde diğer bütün olgularda transperitoneal yol tercih edilmiştir. Ondördü laparoskopik radikal prostatektomi olmak üzere yirmialtı olguda peroperatif ve/veya postoperatif dönemde kan transfüzyonu ihtiyacı duyulmuştur. Bir olgu haricinde intraoperatif açık cerrahiye geçme gereksinimi duyulmamıştır. Bir olguda ise postoperatif 4. günde kanama nedeniyle laparatomi ihtiyacı olmuştur. Altı olguda yüzeyel yara yeri enfeksiyonu gelişmiştir. Ameliyat sonrası ortalama hastanede yatış süresi $3.8 \pm 2.7$ (1-8) gündür. Hastalarımızın ortalama takip süresi ise 16.5 (0-33) aydır.

Sonuç: Laparoskopik ürolojik cerrahiler; teknik olarak iyi tanımlanmış, iyi onkolojik ve fonksiyonel sonuçları olan aynı zamanda kısa yatış süresi ve kozmetik avantajları ile günümüzde sıklıkla tercih edilen minimal invaziv prosedürlerdir. Anahtar sözcükler: Laparoskopi, radikal prostatektomi, nefrektomi, adrenalektomi, pyeloplasti.

\section{INTRODUCTION}

Laparoscopic surgeries have gained an important role in the practice of urology and other surgical fields in recent years, especially in line with the increase in the development of technological equipment. With the first use of laparoscopic surgery in 1976 to diagnose bilateral undescended testes, and then in 1991 with the definition of laparoscopic nephrectomy for the first time by Clayman et al, laparoscopic procedures have begun to be performed all over the world and in our country and they have gained a very important place today ${ }^{1,2}$.

Although steep learning curve and procedures that require intracorporal suture removal are the most important obstacles to the widespread use of laparoscopic surgery, it has become increasingly popular with its advantages such requirement of lower levels of analgesia, smaller incisions, lower morbidity and shorter duration of hospitalization ${ }^{3}$.

In this study; patients who underwent laparoscopic surgery at our department in the past three years were evaluated retrospectively.

\section{MATERIAL AND METHODS}

A total of 244 patients with a mean age of $52.6 \pm$ 17.6 (1-83), including 13 in the pediatric group, who underwent laparoscopic surgery between February 2016 and February 2018 were retrospectively analyzed. 139 of the patients were male and 105 were female. In addition to the examination of the demographic data of the patients, the laparoscopic procedures were analyzed separately and functional and oncological outcomes in the short term were also assessed.

\section{Operative Technique:}

After general anesthesia, nasogastric tube was inserted to all patients before the procedure and 1 gram of cefazolin sodium was administered parenterally to adults for prophylaxis. Transperitoneal approach was preferred in all operations except the laparoscopic radical prostatectomy patients. In patients the treated with radical prostatectomy with supine position, a 3040-degree Trendelenburg position was applied while 50-60-degree lateral decubitus position was preferred in all the other procedures. Open entry of the umbilicus was performed in the pediatric patients, while in adult patients, Veress needle was inserted, insufflation was formed, and pneumoperitoneum was achieved. Intraabdominal pressures were adjusted in the range of 12-14 $\mathrm{mmHg}$ for adults and at $10 \mathrm{mmHg}$ for children. While three 5-mm trocars, one of which was camera port, were used for the pediatric patients, three 11-mm ports were used in the adults. Additional 5-mm trocars were inserted for retraction and excretion if necessary in all procedures.

In all of the transperitoneal cases, the retroperitoneum was reached starting from the Toldt line and medializing descending and ascending colon. Following reaching the renal hilum in laparoscopic radical / simple nephrectomy cases, the first artery and then the vein were closed with polymer Weck clips and the procedures were terminated. As for the laparoscopic partial nephrectomy operation, 
selective polar artery was frequently attempted to be reached, and when not found, the main renal artery was dissected and hanged. Following this, the mass was excised from the demarcation line by achieving warm ischemia with bulldog clamps. Hemostasis of the tumor base was achieved with 4/0 prolactin sutures and fibrin hemostatic agents. In all oncologic cases, malignant tissues were removed from the body in an organ bag.

Radical prostatectomy operations were performed by creating extraperitoneal space with retroperitoneal balloon dilator in the Retzius space. The dorsal vein complex was ligated with bipolar a vessel sealing device or a $2 / 0$ silk suture. After the prostatectomy procedure, ureterovesical anastomosis was achieved continuously with $3 / 0$ monocryl sutures.

After aspiration of cystic content in patients who had renal cyst excision, cyst wall was incised with ultrasonic knives at a few millimeters away from the normal parenchyma and then cauterized later. In all the renal cyst cases, histopathological examination was performed from the cyst wall and cytology was studied from aspiration content.

Endocrinological examinations and tests were completed before laparoscopic adrenalectomy to assess clinical characteristics of all patients and to see whether adrenal masses were functional. After closure of the adrenal vein again with the help of Weck clips, the surrenalectomy procedure was completed.

Removal of narrow segment in laparoscopic Anderson-Hynes dismembered pyeloplasty procedure was performed due to ureteropelvic junction stenosis. After the excess tissue was removed, anastomosis was performed again with $4 / 0$ vicryl sutures through the compressing vein. Immediately before the completion of anastomosis, again in the presence of laparoscopy, 4.0 Fr $12-16 \mathrm{~cm}$ stent was inserted antegradely for the children and 4.8 Fr $28 \mathrm{~cm}$ DJ stent was used for the adults.

In laparoscopic pyelolithotomy and ureterolithotomy surgeries; following removal of the stone from the body after urethrotomy or incision made on the pelvis, D/J stent was implanted. Incisions were then sutured with $4 / 0$ vicryl. In an ureterolithotomy and pyeloplasty case, stone extraction was performed on renal stones with a flexible ureterorenoscope in the presence of laparoscopy.

\section{RESULTS}

Our patients who included in this study were 139 (57\%) male and $105(43 \%)$ female, $13(5 \%)$ were pediatric and the mean age of the patients was $52.6 \pm 17.6$ (1-83). Radical nephrectomy was performed in 47 patients, extraperitoneal radical prostatectomy was performed in 46 patients, simple nephrectomy was performed in 37 patients, renal cyst excision was performed in 35 patients, partial nephrectomy was performed in 26 patients, dismembered pyeloplasty was performed in 25 patients 13 of whom were pediatric, adrenalectomy was performed in in 15 patients, ureterolithotomy was performed in 8 patients, pyelolithotomy was performed in 2 patients, sacrocolpopexy was performed in 2 patients and diagnostic laparoscopy due to undecending testis was performed in 1 patient $(0.4 \%)$.

The mean duration of the operations was $101.9 \pm$ 62.7 (20-270) minutes, the mean durations for each type of surgery were 52.3 (45-110) minutes for simple nephrectomy, 64.3(55-160) minutes for radical nephrectomy, 149.6 (70-140) minutes for partial nephrectomy, 169.7 (130-270) minutes for radical prostatectomy, 41.4 (25-70) minutes for renal cyst excision, 102.4 (75-150) minutes for pyeloplasty, $107.5 \quad(80-120)$ minutes for ureterolithotomy, 90 (70-110) minutes for pyelolithotomy and 109.3 (85-130) minutes for surrenalectomy. During partial nephrectomy, duration of warm ischemia did not exceed 25 minutes in any cases and the mean ischemia time was $18.6 \pm 2.3(14-24)$.

Approximate amount of bleeding was detected as $154.3 \pm 138.7$ (5-800) $\mathrm{ml}$, blood transfusion was performed intraoperatively and/or postoperatively in twenty-six cases, including fourteen with laparoscopic radical prostatectomy. Only in one case, open surgery was started during the radical prostatectomy procedure considering oncological consequences due to excessive adhesion of the prostate tissue in the rectum and seminal vesicles. No intraoperative complications were observed other than this and all procedures were completed laparoscopically. In the postoperative period in another case, hemostasis was achieved with laparotomy which was performed due to gross hematoma that occurred in the retroperitoneal area. In six cases, superficial wound site infection developed in the late postoperative period. However, no complications were encountered in the postoperative period. The mean duration of postoperative hospitalization was $3.8 \pm 2.7$ days (1-8 days). The mean follow-up time of our patients was 17.3 (1-34) months. The demographic data and results of the patients are given in table 1 . 
Table 1. Demographic data and results of the patients

\begin{tabular}{|l|c|}
\hline No. of total patients & 244 \\
\hline No. of paediatric/adult & $13 / 231$ \\
\hline Age, mean \pm SD (range); years, & $52.6 \pm 17.6(1-83)$ \\
\hline No. of female/male & $105 / 139$ \\
\hline No.of Procedures & 47 \\
Radical nephrectomy & 46 \\
Radical prostatectomy & 37 \\
Simple nephrectomy & 35 \\
Renal Cyst Excision & 26 \\
Partial nephrectomy & 25 \\
Pyeloplasty & 15 \\
Adrenalectomy & 8 \\
Ureterolithotomy & 2 \\
Pyelolithotomy & 2 \\
Sacrocholpopexy & 1 \\
\hline Undescended Testicle Surgery & 1 \\
\hline Conversion to open & $154.3 \pm 138.7(5-800)$ \\
\hline Bleeding, mean \pm SD(range);ml & $101.9 \pm 62.7(20-270)$ \\
\hline Operative time, mean \pm SD (range); min. & $3.8 \pm 2.7(1-8)$ \\
\hline Hospital stay, mean \pm SD (range); days. & $17,39 \pm 9,0(1-34)$ \\
\hline Duration of follow-up, mean \pm SD (range); months & $18.6 \pm 2.3(14-24)$ \\
\hline Warm ischemia time in partial nephrectomy, mean \pm SD & \\
(range); min & $13,99 \pm 15,62(4.5-54.9)$ \\
\hline Total PSA, mean \pm SD (range); ng/ml (preoperative radical & \\
prostatectomy patients) & \\
\hline
\end{tabular}

The pathology of all the patients who underwent simple nephrectomy and cyst excision was reported as benign. Of the patients with radical nephrectomy, 37 patients were detected to have clear cell RCC, while 5 had papillary cell RCC, 3 had chromophobe cell RCC and 2 had high grade urothelial carcinoma. Of the 26 patients who underwent partial nephrectomy, 17 was detected to have clear cell RCC while 4 had angiomyolipoma, 1 had oncocytoma, 1 had chromophobe cell RCC, 1 had multicystic clear cell RCC, 1 had papillary renal cell RCC and 1 had neuroendocrine cell tumor metastasis. Surgical margin was found positively only in one patient in partial nephrectomy group; and the patient was taken into follow-up.

In the laparoscopic radical prostatectomy cases; the mean amount of bleeding was found as 348.7 \pm 207.4 (100-800) $\mathrm{ml}$. The mean duration of uretero-vesical anastomosis was $28.4 \pm 6.6(18$ 40) minutes. Laparotomy was required due to hemorrhage on the 4th postoperative day in one case. The mean preoperative PSA level of the cases was 13,99 $\pm 15,62 \quad(4.5-54.9)$. The pathological grade pT2 was detected in $90.5 \%$ of the cases and the pathologic grade of pT3 was found in $8.6 \%$ (4/46). Two cases requiring adjuvant RT were reported, surgical margin positivity ratio was calculated as $4.3 \%$. During approximately 13 months of follow-up, the biochemical recurrence rate was $2.1 \%$ (1 patient). In postoperative term; total continence was observed in 27 patients (58.7\%) whereas minimal stress incontinence (1 pad/day) and severe urinary incontinence requiring surgical intervention was occurred in $17(36.9 \%)$ and 2 patients $(4.3 \%)$; respectively. Potency was observed in $42.3 \%$ of the patients eligible for potency (11/26).

\section{DISCUSSION}

Laparoscopic surgery in urology has shown rapid progress in recent years and has become widely available and preferred in many ways. The most important reason for this is the technological progress in the equipment used in laparoscopy and imaging systems ${ }^{4}$. Additionally, 3D and and advanced digital imaging systems developed in recent years have enabled significant improvements in the quality of imaging in minimally invasive surgeries. Three-dimensional imaging provides surgical advancement in sensitive minimally invasive procedures, particularly renal pedicle dissection. This feature 
makes laparoscopy a lot easier for beginner surgeons for complex works requiring expertise, such as sutures and knots ${ }^{5}$.

There is no difference between laparoscopic surgery and open surgery in terms of oncologic outcomes. It has become increasingly popular among patients with its short hospitalization period, early mobilization, cosmetic superiority, lowered use of postoperative analgesics, short hospitalization and rapid onset of daily activity ${ }^{6,7}$.

Lack of sense of touch, view from a narrow angle, lack of flexibility of hand tools, limited working area and difficulty of intracorporeal suture techniques are seen as disadvantages of laparoscopic surgeries ${ }^{8}$. Laparoscopic surgeries have specific complications. Hyperparasia may develop due to $\mathrm{CO} 2$ insufficiency. In order to prevent this, intraabdominal pressure should be kept in the range of $12-15 \mathrm{mmHg}$. Other specific complications may occur during insertion of Veress needle. When the literature is examined in terms of complications, it was reported that vascular injuries, which are considered as major injuries, are seen by 0.03-2.7\% and bowel injuries are seen by $0-0.9 \% 9-11$. It is accepted that complication rates are very low especially in experienced centers ${ }^{12}$. Urologists interested in laparoscopic surgery should definitely go through a basic laparoscopy training. This training is usually long-term. Proper choice of patient and good planning and preparation before surgery will reduce the complication rate. We are linking the fact that we have not experienced major complications in our series with our current laparoscopic surgical experience. In our study; only one patient in laparoscopic radical prostatectomy group who needed converting to open surgery due to periprostatic tissue and seminal vesicle invasion.

Laparoscopic urological operations are performed with two different approaches, transperitoneal and retroperitoneal. In the transperitoneal approach, the surgeon has a wider operative area and more maneuverability. The nephrectomy operations performed with the transperitoneal approach have been shown to be performed in a shorter time ${ }^{13}$. However, the choice of method depends on the surgeon's experience and preferences. In our study, the transperitoneal approach was preferred in all cases except radical prostatectomy operation.

Clear cell RCC constitutes $70-80 \%$ of all RCCs and $10-15 \%$ of papillary RCCs ${ }^{14}$. In our study, as a result of histopathological examinations of the laparoscopic radical and partial nephrectomy cases; 54 (\%73.9) clear cell RCC, 6 (\%8.2) papillary cell RCC, 4 (5.4\%) chromophobe cell RCC, 4 (5.4\%) angiomyolipoma, 2 (2.8\%) urothelial carcinoma, 1 (1.3\%) oncocytoma, 1 (1.3\%) multicystic clear cell RCC, 1 (1.3\%) neuroendocrine cell tumor metastasis were reported, and these results were found to be consistent with literature Operative time is generally longer with the laparoscopic approach and warm ischaemia time is shorter with the open approach $^{15}$. Glomerular filtration rate (GFR) decrease was greater in the laparoscopic partial nephrectomy group in the immediate postoperative period but not after follow-up of 3.6 years ${ }^{16}$. A positive surgical margin ratio is encountered in $8 \%$ of all partial nephrectomies ${ }^{17}$. We observed surgical margin positively in only one patient and our warm ischemia time was under 25 minutes in all laparoscopic partial nephrectomy patients.

When the pathological findings of 15 patients with laparoscopic surrenalectomy were examined, 7 (\% 46.7) adrenocortical adenomas, 5 (33\%) pheochromocytomas, 1 (6.6\%), papillary cell RCC metastasis, 1 (33.3\%) myelolipoma and 1 (6.6\%) adrenal cyst were detected. In the series of 101 diseases prepared by Parnaby et al; benign adrenal mass was detected in 70 patients, nonfunctional adrenal tumor was detected in 5 patients, adrenal carcinoma was detected in 17 patients, metastatic adrenal carcinoma was detected in 3 patients, contralateral adrenal carcinoma metastasis was detected in 3 patients, retroperitoneal sarcoma was detected in 2 patients and mixed type adenoma was in 1 patient. They had similar results to those our study. Moreover, the laparoscopic approach was identified as applicable and safe for adrenal masses above $6 \mathrm{~cm}$ 18.

In radical prostatectomy; the 5-year PSA progression-free rates for open, laparoscopic and robotic surgical techniques were reported as $80 \%$, $75 \%$, and $91 \%$ respectively ${ }^{19}$. The value accepted for biochemical recurrence was identified as 0.1 $\mathrm{ng} / \mathrm{mL}$ and as increasing PSA. We performed laparoscopic radical prostatectomy in low and intermediate risk group patients. Biochemical recurrence was observed in only one patient in laparoscopic radical prostatectomy group during the mean follow-up of 17 months. Stolzenburg et al. reported their continence rates in 700 patients who underwent laparoscopic radical prostatectomy after six months were $83.8 \%{ }^{20}$. In our data; of the patients $57.1 \%$ had complete continence, $40.4 \%$ (1 pad / day) had minimal stress incontinence and $2.3 \%$ had incontinence 
requiring surgical intervention, respectively. Thus difference in continence rate might be the result of our early findings and begining of the experience in extraperitoneal prostatectomy. Positive surgical margins were found in $9.7 \%$ of patients with a pT2 tumor and in $34.4 \%$ of patients with a pT3 tumor in large series ${ }^{21}$. We observed only two surgical margin positivity in all patients. Our surgical margin positivity rate was lower because of most of the cases were localized low risk prostat carcinoma.

Laparoscopy has become a more popular and preferred method in urology due to being a more minimally invasive procedure, its shorter duration of hospitalization, cosmetic advantages and low morbidity rates as well as oncological results similar to open surgery. Preoperative patient choice, a good preparation process and experienced team work are other important factors in success.

\section{REFERENCES}

1. Cortesi N, Ferrari P, Zambarda E, et al. Diagnosis of bilateral abdominal cryptorchidism by laparoscopy. Endoscopy 1976: 8; 33-4

2. Clayman RV, Kavoussi LR, Soper NJ, et al. Laparoscopic nephrectomy: initial case report. J Urol 1991; 146: 278-82.

3. Jain S, Jain SK, Kaza RCM, Singh Y. This challenging procedure has successful outcomes: Laparoscopic nephrectomy in inflammatory renal diseases. Urol Ann. 2018; 10: 35-40.

4. Cwach K, Kavoussi L. Past, present, and future of laparoscopic renal surgery. Investig Clin Urol 2016; 57 (Suppl 2): 110-3.

5. Kunert W, Storz P, Müller S, Axt S, Kirschniak A. 3D in laparoscopy: State of theart. Chirurg 2013; 84: 202-7.

6. Fornara P, Doehn C, Friedrich HJ, Jocham D. Nonrandomized comparison of open flank versus laparoscopic nephrectomy in 249 patients with benign renal disease. EurUrol 2001; 40: 24-31.

7. Gratzke C, Seitz M, Bayrle F, et al. Quality of life and perioperative outcomes after retroperitoneoscopic radical nephrectomy (RN), open $\mathrm{RN}$ and nephron-sparing surgery in patients with renal cell carcinoma. BJU Int 2009; 104: 470-5.

8. Gill IS, Kavoussi LR, Clayman RV, et al. Complications of laparoscopic nephrectomy in 185 patients: a multi institutional review. J Urol 1995; 154 : 479-83.

9. Siqueira Jr TM, Kuo RL, GardnerTA, et al. Major complications in 213 laparoscopic nephrectomy cases: the Indianapolis experience. J Urol 2002; 168: 1361-5.

10. Permpongkosol S, Link RE, Su LM, et al. Complications of 2,775 Urological laparoscopic procedures: 1993-2005. J Urol 2007; 177: 580-5.

11. Michael S. Lasser, Reza Ghavamian. Surgical complications of laparoscopic urological surgery. Arab J Urol 2012; 10 (1): 81-8.

12. Jarrett TW, Chan DY, Charambura TC, Fugita O, Kavoussi LR. Laparoscopic pyeloplasty: The first 100 cases. J Urol 2002; 167: 1253-6.

13. Chan DY, Cadeddu JA, Jarrett TW, Marshall FF, Kavoussi LR. Laparoscopic radical nephrectomy: cancer control for renal cell carcinoma. J Urol 2001; 166 : 2095-9.

14. Baldewijns MM, vanVlodrop IJ, Schouten LJ.et al. Genetics and epigenetics of renal cell cancer. Biochim Biophys Acta 2008; 1785: 133-55.

15. Gong EM, Orvieto MA, Zorn KC, et al. Comparison of laparoscopic and open partial nephrectomy in clinical T1a renal tumors. J Endourol 2008; 22: 953-7.

16. Shah PH, Moreira DM, Okhunov Z, et al. Positive Surgical Margins Increase Risk of Recurrence after Partial Nephrectomy for High Risk Renal Tumors. J Urol 2016; 196: 327-34.

17. Marszalek M, Meixl H, Polajnar M, et al. Laparoscopic and open partial nephrectomy: a matched-pair comparison of 200 patients. Eur Urol 2009; 55: 11718.

18. Parnaby CN, Chong PS, Chisholm L, et al. The role of laparoscopic adrenalectomy for adrenal tumours of 6 cm or greater. Surg Endosc 2008; 22: 61721.

19. Nelson JB. Debate: open radical prostatectomy vs. laparoscopic vs. robotic. Urol Oncol 2007; 25: 490-3.

20. Stolzenburg JU, Rabenalt R, DO M, et al. Endoscopic extraperitoneal radical prostatectomy: oncological and functional results after 700 procedures. J Urol 2005; 174: 1271-5. 
21. Stolzenburg JU, Rabenalt R, Do M, Kallidonis P, Liatsikos EN. Endoscopic extraperitoneal radical prostatectomy: the University of Leipzig experience of 2000 cases. J Endourol 2008; 22: 2319-25. 